\title{
Derleme
}

\section{Sağlık bilimleri alanında bilimsel makale yazma teknikleri}

\author{
Kansu Büyükafşar \\ Mersin Üniversitesi Tıp Fakültesi Tıbbi Farmakoloji AD, Mersin
}

$\ddot{0} \mathbf{z}$

Bu derlemede, bir bilimsel çalışmanın bulgularının nasıl etkili, dengeli ve ilgi çekici bir şekilde kaleme alınacağına dair bir takım yöntem, teknik ve ipuçları bulacaksınız. Bir makaleyi yazmaya başlamadan önce yapılması gereken en önemli husus, o konuyla ilgili daha önce yayımlanmış makalelerin mutlaka iyi okunması ve anlaşılmasıdır. Ayrıca makalesi yazılacak çalışmanın bulguları en iyi şartlarda elde edilmeli ve bunların doğruluğundan emin olunmalıdır. Makaleyi kaleme alacak kişi(ler), tüm bulgulara hakim olmalıdır. Bunlar yapılmadığı takdirde makale yazmak, oldukça zor, sıkıcı ve yavaş ilerleyen bir hal almaktadır. Kötü yazılmış bir makalenin ret edilme ihtimali oldukça yüksektir. İlgili çalışma daha önce projelendirildiyse (TÜBİTAK, BAP gibi) detaylı literatür taranması yapılmış, konuya hakim olunmuştur ve bu durumda makalenin bulgularını yazmak, onları yorumlamak daha da kolaylaşacaktır. Bir makaleyi doğru ve etkileyici bir şekilde kaleme almak şüphesiz önemlidir. Ancak çalışma verileri yeterince önemli ve değerliyse, yayımlanan eser eninde sonunda hak ettiği ilgiyi çeker. Yine de, bir makalenin evrensel normlarda kabul edilen kurallar çerçevesinde yazılması gerekmektedir. Bunun için baştan sona titiz davranılmalıdır. Aslında pek çok bilim dalında her yıl yayımlanan binlerce makalenin genellikle az bir kısmı oldukça yenilikçidir. Yani, pek çok araştırma, aslında daha önce yayımlanmış makalelerin genellikle başka açılardan tekrarı veya onların tamamlayıcısıdır. $\mathrm{Bu}$ durum, daha önce yayımlanmış olan verilerin başka araştırmacılar tarafından doğrulanması bakımından şüphesiz çok önem taşımaktadır. Bilimselliğin en önemli öğelerinden biri olan doğrulanabilirlik açısından, bir bilim insanının elde ettiği bulguların başka bilim insanlarınca da tekrarlanması gerekmektedir. $\mathrm{Ne}$ var ki, böyle yayımların orijinal ve yenilikçi makalelerin sağladığı etkiyi oluşturması beklenemez. Bu bakımdan çalışmanın bir şekilde parlatılması ve ilgi çekici hale getirilmesi, yazarların atıf (sitasyon) alma talepleri açısından önemlidir.

Anahtar kelimeler: Bilimsel yazı, iyi makale yazma, yayın

\section{Techniques about writing a scientific article in health sciences}

\begin{abstract}
In this review, you will find some consistent tips and techniques on how to write a scientific paper in an effective and appealing way. Prior to writing a manuscript, one crucial thing is to prevail the relevant literature on the subject of the article in question. Moreover, findings of the manuscript must be obtained in optimum conditions, so that the accuracy of the data can be assured when published.
\end{abstract}

Yazının geliş tarihi :16.06.2017 Yazının kabul tarihi :09.11.2017

Sorumlu yazar: Prof. Dr. Kansu Büyükafşar. Mersin Üniversitesi Tıp Fakültesi Tıbbi Farmakoloji AD, 33343 Yenișehir/ Mersin, Tel: 0(324)3610684/29118, E-posta: kansu23@yahoo.com 
Plus, all data set of the study must be comprehended well by the writer(s). Otherwise, writing a manuscript can be so difficult and even disturbing, thus can be a waste of valuable time. A poorly written manuscript is most likely to be rejected. If the study's theme was already submitted for grant application such as TUBITAK (The Scientific and Technological Research Council of Turkey), BAP (Intramural University Projects) etc.., it is supposed to be relevant and concordant with the latest developments of the literature. In this context, the writing process can be more comfortable and easier. There is no doubt that a scientific article must be written accurately and in an appealing way that attracts the readers. Nevertheless, if findings of the study is significant enough, it will eventually deserve its worth value. No matter how it's written, an article needs to be presented in accordance with the internationally accepted norms of scientific writing. For this, the writing process must be scrutinized and elaborated from the beginning to the end. In fact, among thousands of articles published every year, only a few of them are so innovative, i.e., yet the majority are circumstantial and confirmative. This is absolutely essential that others ascertain earlier studies in the sense of repeatability and verifiability in scientific studies. However, this does not necessarily guarantee to produce a high impact as much as occurred in the innovative studies. Therefore, a scientific paper needs to be well written, polished and appealing for the demand of authors to get higher citations.

Keywords: Good writing, scientific writing manuscript, paper

\section{Giriş}

Lisansüstü eğitimde makale, tez ve benzeri proje çıktıların nasıl kaleme alınacağı konusu genellikle fazla vurgulanmaz. Bu konuda daha ziyade öğrencinin araştırarak, sorarak kendini geliștirmesi istenir. Danıșman ve mentörler bilimsel bir yazının nasıl kaleme alınacağı konusunda öğrencilerine genellikle fazla vakit ayırmazlar. Çerçevesi çizilmiş bir eğitim müfredatı da pek yoktur. Tez danışmanları ya da sorumlu hocalar yeri geldiğinde, danışmanlığında bulunan öğrencilere makale, proje ya da kongre bildirisini yazmalarını isterler. Ancak genç araştırmacı bunu nasıl yazacağını pek bilmez ve çevresinden destek aramaya başlar. Daha önce yayımlanmış eserleri inceleyerek ya da etrafinda bulunan kendine göre tecrübeli kişilerden aldığ bilgilerle bildiri, makale ya da tezini yazmaya bașlar. $\mathrm{Bu}$ süreçte doğru-yanlış bilgiler edinir ve deneyimleyerek öğrenmeye çalışır. $\mathrm{Bu}$ durum, lisansüstü eğitim-öğretim müfredatında makale yazma eğitiminin aslında ne kadar gerekli olduğunu göstermektedir. Neyse ki, şimdilerde bu tür eğitim faaliyetleri artmaktadır ve lisansüstü eğitim müfredatlarına tez, makale ve bildiri yazma gibi, dersler girmektedir.

Bilim dünyasında doğal olarak, hep bilimsel çalışmanın kalitesine dem vurulur.
Şüphesiz yayımlanacak bulguların orijinalliği, yenilikçi tarafı çok önemlidir. $\mathrm{Ne}$ var $\mathrm{ki}$, bir çalışmaya ait verilerin etkili, dengeli, doyurucu ve kolay anlaşlabilir bir şekilde kaleme alınması ve ayrıca makalenin keyifle okunması da, bir o kadar önemlidir. Çok jargonlu, anlaşılmaktan uzak ve gereksiz uzun yazılmış bir makale ile verilerin derli toplu sunulduğu, yalın ve anlaşılabilir bir makalenin okuyucuda bıraktığı izlenim elbette farklı olacaktır. Okuyucu, işine yarayan, kolay anladığı bir makaleyi okumaktan daha fazla keyif alır ve bunu daha kolay "refere" eder. Bilimsel bir makaleyi kaleme alırken dikkat edilmesi gereken en önemli husus, ilgili makalenin okuyucunun anlayabileceği kadar basit ve yalın yazılmış olmasıdır. Ancak makale ya da benzeri yayını yazmadan önce yapılması gereken önemli noktalardan biri de, o konuyla ilgili daha önce yayımlanmış makalelerin mutlaka iyi okunması ve anlaşılmasıdır. Diğer taraftan makalesi yazılacak çalışmanın verileri en iyi şartlarda elde edilmelidir. Bulguların doğruluğundan emin olunmalıdır. Ayrıca, makaleyi kaleme alacak kişi tüm bulgulara hâkim olmalıdır. Bunlar yapılmadığı takdirde makale yazmak, oldukça zor, sıkıcı ve yavaş ilerleyen bir hal almaktadır. İlgili çalışma daha önce projelendirildiyse (TÜBİTAK, BAP gibi) detaylı literatür taranması 
yapılmıș, konuya hakim olunmuștur ve bu durumda makalenin bulgularını yazmak, onları yorumlamak daha da kolaylaşacaktır. Ancak proje başladıktan sonra veriler gelince bazen çalışma apayrı bir yere gidebilir. Dolayısıyla yeni konulara ve açılımlara da hazır olunmalıdır.

Bir bilimsel araștırmadan elde edilen veriler yeterince önemliyse, yayımlanan eser, eninde sonunda hak ettiği ilgiyi çeker. Yine de, bir makalenin evrensel normlarda kabul edilen genel kurallar çerçevesinde yazılması, doğru ve etkili bir şekilde sunulması gerekmektedir. Bunun için baştan sona titizlikle yazılmalıdır.

Aslında pek çok bilim dalında her yıl yayımlanan binlerce makalenin genellikle az bir kısmı oldukça yenilikçidir. Yani, pek çok araştırma, daha önce yayımlanmış makalelerin genellikle bașka açlardan tekrarı veya onların tamamlayıcısıdır. Bu durum, daha önce yayımlanmış olan verilerin başka araștırmacılar tarafından doğrulanması bakımından şüphesiz çok önemlidir. Bilimselliğin en önemli öğelerinden biri olan doğrulanabilirlik açısından, bir bilim insanının elde ettiği bulguların başka bilim insanlarınca da tekrarlanması gerekmektedir. $\mathrm{Ne}$ var ki, böyle yayımların orijinal ve yenilikçi makalelerin sağladığı etkiyi oluşturması beklenemez. Bu bakımdan çalışmanın bir şekilde parlatılması ve ilgi çekici hale getirilmesi, yazarların atıf alma talepleri açısından önemlidir.

Sağlık bilimleri alanında yayımlanmak üzere kaleme alınan bir makale taslağının (manuscript) bölümleri, genel olarak, IMRAD (Introduction, Methods, Results and Discussion) kisaltmasiyla tanımlanmaktadır. ${ }^{1-4,}$ 6-9 Daha detaylı olarak bir makalenin bölümleri şu şekilde siralanabilir:

1. Başlık (Title)

2. Kısa başlık (Running title, short title)

3. Yazarlar ve siralaması (Authors)

4. $\quad$ Adres (Address)

5. Özet (Abstract, summary)

6. Anahtar kelimeler (Keywords)

7. Giriș (Introduction)

8. Materyal ve metod (Materials and Methods)
9. Bulgular (Results, Key Findings)

10. Tartışma (Discussion)

11. Sonuç (Conclusion)

12. Teşekkür (Acklowledgement)

13. Kaynaklar (References)

Şimdi bütün bu bölümlerin nasıl kaleme alınması gerektiği konusunda bir takım öneriler ve ipuçları bulacaksınız. Bilimin evrensel dili İngilizce olduğu için örneklemelerin hemen tamamı İngilizce olarak verilmiştir, çevirisi yapılmamıştır.

\section{Başlık (Title)}

Başlık bir makalenin en can alıcı kısmıdır. Okuyuculara ilk etki burada bırakılır. Başlık, okuyucuya genel bir değerlendirme yapmaya olanak sağlayacak anahtar kelimeleri içermelidir. ${ }^{1-4}$ Bir makale başlığı nasıl olmalıdır?

- Başlık konuyla ilgili, kapsamlı, çarpıcı ve etkileyici olmalıdır. Örneğin " $A$ phylogenetic analysis of humans and chimps" yerine "Phylogenetic evidence indicates an exceptionally close relationship between humans and chimps" yazmak, başlığı daha ilgi çekici hale getirecektir. $^{2}$

- Aşırı sifat ve isim tamlamalarından kaçınılmalıdır." Örneğin, "Inhibition of Hedgehog signal transduction pathwayinduced facilitation of migration of murine-derived macropaheges by COX inhibitors" bu şekilde yazılan başlık okuyucunun takibini ve anlamasını zorlaştıracak ve okuyucu belki de makaleyi okumaya devam etmeyecektir.

- Sade ve anlaşılabilir olmalıdır fakat çok genel ve çok ortada bir başlık da kullanılmamalıdır. Örneğin, "Studies on bacteria" şeklinde yazılmamalıdır; çalışmanın bütününe bakıldığında somut bir anlam ifade edebilmelidir. ${ }^{2}$

- Çok uzun ve karmaşık olmamalıdır, mümkün olduğunca kısa olmalıdır. Örneğin, "Differential effects of two janus kinase (JNK) inhibitors, $\mathrm{H}-752$ and $\mathrm{XO}$ 89581 and mitochondrial membrane transition inhibitor, BR-RD-611 on lung injury as a far organ damage after endotoxemia elicited by cecal ligation and 
puncture in rats" şeklinde yazılmış bir başlığın pozitif ilgi çekmesi beklenemez.

- Çalışmanın geneline kuş bakışı baktığımızda ön plana çıkan bulgu ve bilgiler başlıkta bulunabilir. Ayrıca, başlık materyal-metod, bulgu, bilgi ve hatta sonuç da içerebilir (Şekil 1, 2).

Başlık, seyrek olarak bir soru da olabilir. Örneğin, "Can glyceryltrinitrate replenish photosensitive NO stores?" Makale başlı̆̆l, evrensel bir doğru olarak sunulmamalıdır, örneğin, "Adenylyl cyclase is upregulated in liver by endotoxin". $2 \mathrm{Bu}$ bașlı̆̆ın yerine olasılık ifadelerinin kullanılması daha doğru olur. Örneğin, "Adenylyl cyclase could (can, might) be upregulated in liver by endotoxin".

\section{Kısa Başlık (Running title, short title)}

Bir-iki kelimeyle çalıșmayı özetleyen ifadedir. Örneğin,

- Arrhytmias by oubain

- Rho in sepsis

- ARDS and ROCK

\section{Yazarlar ve Siralaması (Authors)}

Vancouver anlaşmasında alınan karalara göre sağlık bilimleri alanında yayın yapan dergilerde yazar olmanın koşulları şu şekilde sıralanmıştır. ${ }^{5}$

- Çalışmanın planlanması, tasarımı, analizi veya yorumlanmasına katkıda bulunmak

- Yayını hazırlamak veya önemli ölçüde düşünsel katkı yaparak düzeltmek

- Yayınlanacak metnin son şekline onay vermek

Bir makalede yazar siralaması konusunda, maalesef herkes tarafindan kabul edilen, bir uygulama yoktur. Dolayısıyla yazar sıralamasında eğilimler değişkenlik gösterebilir. Genel eğilim, çalışmayı/projeyi yöneten kişinin (director) son isim olması ve çalışmayı yürüten genç araștırıcının da ilk isim olmasıdır. ${ }^{5}$ Diğer yazarların katkı nispetinde baştan başlayarak sıralanmasıdır. Ancak proje yürütücüsü de gerektiğinde ilk isim olabilir. Doktora tezlerinden üretilen makalelerde tez sahibi ilk isim olur. Yazarlar içinden biri dergi ile iletişimi sağlar, buna

"corresponding author" denir. Makaleye katkı açısından bu yazar ile diğer yazarlar arasında fark yoktur. Ülkemiz bilim insanlarınca "corresponding author" olmanın bir avantajı olduğuna dair maalesef yanlış bir kanı vardır. Oysa bu yazar, sadece iletişimi sağlar ve organize eder.

\section{Adres (Address)}

Calıșmanın

klinik/laboratuar/bölümlerin adresi yazılmalıdır. İletișimin sağlanacağı kiși ("author for correspondence, corresponding author") iletişim adresini çalıştı̆̆ kurumun adresinden farklı bir adresi verebilir. Çalışma birden fazla laboratuarda yapılmışsa her bir adres yazar isimleri üzerine eklenmiş sembollerle (a,b,c veya 1,2,3 gibi) aşağı satırlarda açıklanır. ${ }^{1-4}$ (Şekil $3)$.

\section{5. Özet (Abstract, summary)}

Bașlıktan sonra en fazla okunan makale bölümüdür. Araştırmacılar öncelikle taradıkları makalelerin başlıklarına bakarlar, ilgili bulurlarsa özetine geçerler. Genellikle abonelik gerektirmediği ve internet ortamında kolay ulaşılabilir olduğu için herkesin kullanımına açıktır. Dolayısıyla özet mümkün olduğunca çok okuyucuyu kapsar şekilde kaleme alınmalıdır. Konuyla fazla ilgisi olmayan okuyuculara hitap edecek kadar da yalın yazılmalıdır. Esasında özet, bütün makalenin kısaltılmıș ve bir paragraf halinde sunulmuş şeklidir. Aynı makale gibi hipotez ve/veya amaç, materyal ve metot, bulgular ve sonuç içerir. Dergi kurulları ve editörler makale özetlerinin belli sayıda kelimeyi aşmamasını isterler. Dolayısıyla özet, en az kelimeyle en fazla bilginin aktarıldığ bölümdür. İlgili ve önemli bilgilerden bahsedilmelidir. Çekici olmalıdır ve kusursuz yazılmalıdır. .-9 $^{-9}$

Merak uyandıracak şekilde kaleme alınmalı ve makalenin de okunmasını teşvik edecek şekilde düzenlenmelidir (6).

Özet mümkünse "kantitatif" olmalıdır. ${ }^{4}$ Şöyle ki, bulguları ifade ederken azalttı, artırdı veya değiştirmedi gibi ifadelerden ziyade, sayısal değerler de verilmelidir. Örneğin "Kontrol grubunun vazodilatasyon ortalaması $\% 23.4 \pm 2.0$ iken kalsiyum kanal blokörü nifedipin grubunun 
ortalaması \% 65.5 \pm 3.8 idi $(P<0.01) "$ gibi. Özeti kaleme alırken dikkat edilmesi gereken hususlar genel olarak şunlardır:

- Özet kısmında hipotez ya da amaç, bir cümleyle yazılabilir. Materyal ve metoddan ve temel yöntemlerden mutlaka bahsedilmelidir. Örneğin deney hayvanında kimyasal bir madde ile diyabet modeli oluşturulmuşsa bu amaçla kullanılan ajanın dozu, veriliş yeri, sıklığ (çözücünün ne olduğu) gibi bilgiler verilmelidir.

- Bunu takiben kısaca yeni veya önemli bulgular ve varsa anlamlı değişmeler $(P<0.05$ gibi) yazılmalıdır.

- Son olarak bu çalışmada varılan yargl/sonuçtan (conclusion) bahsedilmelidir.

Bazı dergiler, özeti de makale gibi alt başlıklara ayırmaktadır. Örneğin,
- Background/Aim

(Geri

plan, zemin/amaç)

- Materials and methods (Materyal ve metodlar)

- Results (Bulgular)

- Conclusion (Sonuç)

Böyle bir ayrımın yapılmadığı dergilerde ise özet, bu silsile ile alt başlıklar olmadan yazılmalıdır.

Grafik Özet (Graphical Abstract)

Bazı dergiler, özellikle derleme çalışmaları için grafik halinde sunulmuş özet isteyebilirler. Bu durumda çalıșmayı özetleyen ya da ön plana çlkan önemli bulguların görsel sunum şekilleri verilir. Örneğin bir ameliyat tekniği ya da sinyal yolaklar ya da sistematik sınıflandırma gibi (Şekil 4).

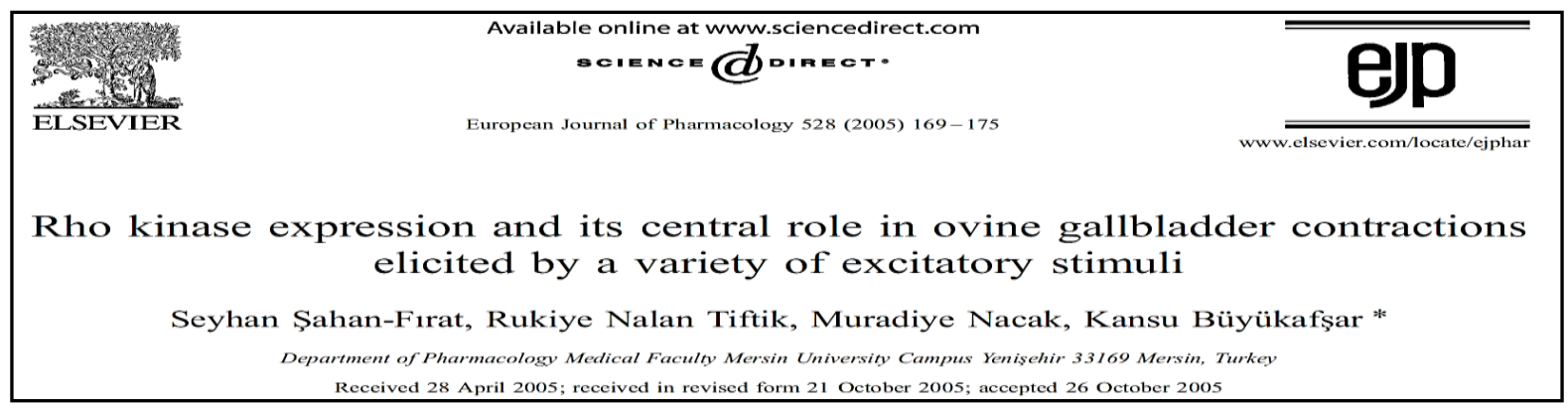

Şekil 1. Makale başlığının yazılmasına bir örnek. ${ }^{10}$ Bu örnekte başlığın kapsamı, bilinçli ve doğru olarak, geniş tutulmuştur çünkü düz kas kasılması, safra kesesi çalışmaları, eksitatör uyarılar ve Rho-kinaz konusuyla ilgilenen araştırıcılar hedef alınarak başlık kapsamlı bir şekilde yazılmıştır.

\section{British Journal of Pharmacology (2001) 132,165-172 $\quad$ (C) 2001 Nature Publishing Group All rights reserved 0007-1188/01 $\$ 15.00 \quad$ C \\ Formation of nitric oxide from nitroxyl anion: role of quinones and ferricytochrome c}

'Kansu Buyukafsar, ${ }^{2}$ Silvia Nelli $\&{ }^{*, 2}$ William Martin

Şekil 2. Makale başlığının yazılmasına bir başka örnek ${ }^{11}$. Bu başlıkta ise hem nitroksil anyonu, hem nitrik oksit hem de kinon bileşikleri, sitokrom, demir ve bunlar arasında bağlantı kurulduğunda anlaşılacağı üzere elektron transport zinciri ile ilgilenen araştırmacıların dikkatini çekmek amacıyla yazılmıștır.

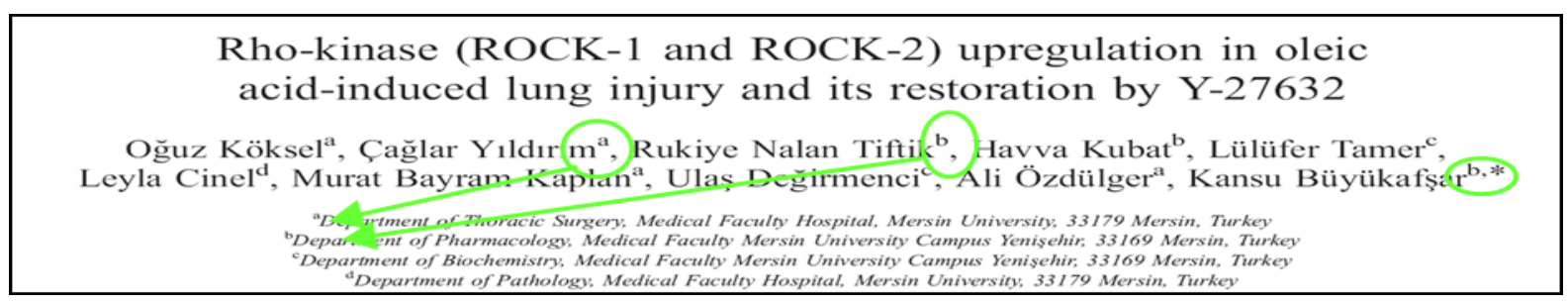

Şekil 3. Yazar adreslerinin gösterilmesine bir örnek ${ }^{12}$. Burada yazarların adresleri üst simge şeklinde harflerle gösterilmiștir. Ayrıca rakamlarla veya bașka sembollerle de gösterilebilir. 


\section{Anahtar Kelimeler (Keywords)}

Çalışmayı kapsayacak ve onu ifade edecek kelimelerdir. Sayıca genellikle 5-10 arasında olması istenir. Anahtar kelimeler sayesinde makale indekslenir ve bulunur. Anahtar kelimeleri yazmanin en kolay yolu "Bu makaleyi bulmak için ne tür anahtar kelimeler seçerdim" sorusunun cevabını vermektir. Örneğin, Keywords: Carbachol; cholecyctokinin; human gallbladder; rhokinase, $Y$-27632 gibi

\section{Giriş (Introduction)}

Çalışmanın amaç ve hipotezi bu kısımda okuyucuya sunulur. Hipoteze dayanak teşkil eden bilgiler verilir.1-9 Çalışmanın en önemli bölümlerinden biridir. Literatür taraması ve bunlara hâkimiyet gerektirir. Okuyucu, kısa genel bilgiler ve çalışma konusuyla ilgili özel bilgilerle hipotez noktasına peyder pey çekilir ve en sonunda çalışmanın hipotezi veya amacı ortaya atılır. Aslında giriş kısmının bir amacı vardır. $0 \mathrm{da}$, okuyucunun bu makaleyi neden okuması gerektiği konusunda ikna etmektir. Bunu yaparken okuyucunun makalede önemli, somut ve bilimsel bir soru sorulduğu konusunda tatmin edilmesi gerekir.

Makalenin giriş bölümü çok uzun olmamalı ve mevcut literatür bilgileri öz olarak sunulmalıdır. Okuyucu çabuk sıkılır ve dikkati dağllır. Konuyu anlamakta zorluk çekerse makaleyi okumaktan vazgeçebilir. Çalışmada cevabı aranan sorular açık ve net bir şekilde ortaya konmalıdır. ${ }^{1-9}$ Genellikle makale yazma konusunda fazla deneyimi olmayan araştırıcılar giriş kısmını çok geniş tutarlar ve gerekli-gereksiz kitabi ya da derleme bilgileri sunarlar. Fazla bilgi vermenin ve fazla kaynak kullanmanın çalışmayı daha değerli kılacağına dair yaygın bir yanlış kanı vardır.

Giriş bölümünde zaman zaman metoda ilişkin yaklaşımlar yapılarak amacın ve hipotezin doğru bir şekilde uygulamaya konulduğu izlenimini verebilirsiniz. Örneğin, araştırmanın hipotezi ortaya konulduktan sonra, bir dokuda bir enzim düzeyini ya da aktivasyon derecesini araştırıyorsanız bu araştırma işini hangi yöntemle yaptığınızı ismen (örneğin Western blot analizi gibi.) yazabilirsiniz.

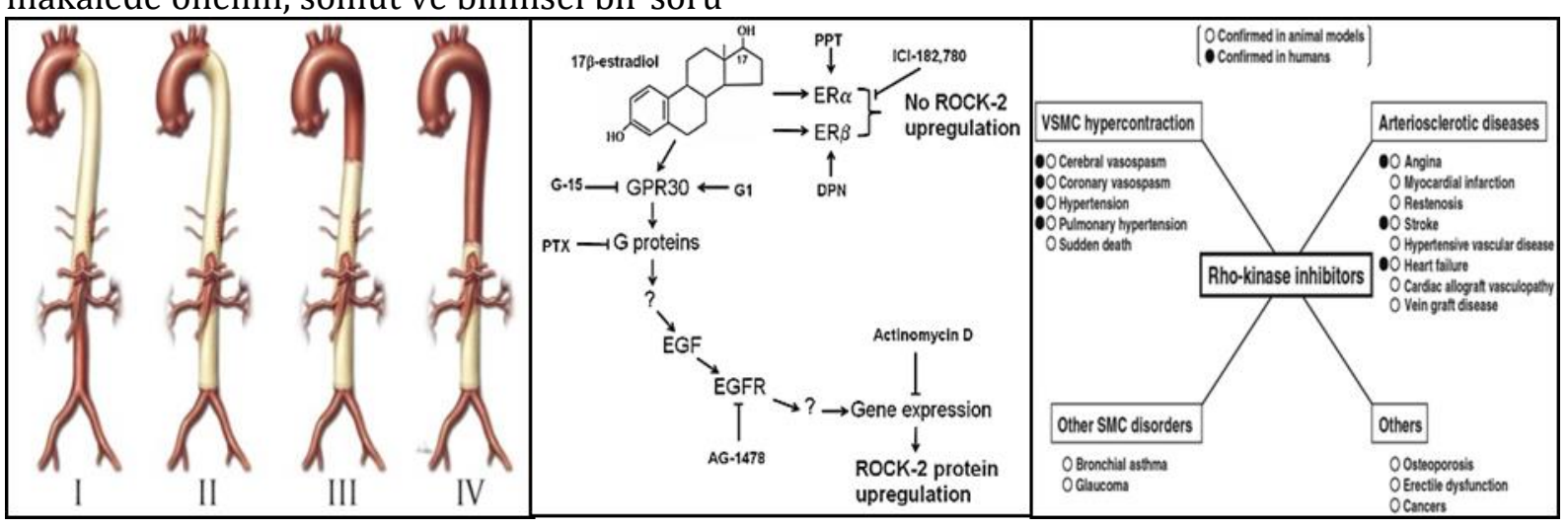

Şekil 4. Grafik özetlerinin çizilmesine ait çeşitli örnekler. Soldaki ilk grafik özette ${ }^{13}$, aort anevrizmasının cerrahi onarımının temsili şematik görünümü görülmektedir. Ortadaki grafik özette ${ }^{14}$ östrojen reseptörleri ile Rho/ROCK sinyal yolağı arasındaki tahmin edilen olası ilişki gösterilmektedir. En sağdaki grafik özette ${ }^{15}$ ise Rho/Rho-kinaz yolağının inhibisyonunun terapötik fayda sağlayabileceği hastalıklar özetlenmiştir.

Böylece hipotezi geçerli metotlarla test ettiğinizi ortaya koymuş olursunuz.

Makalenin giriş kısmını yazarken, benzetme yapmak gerekirse, bir huni şeklinde yapılandırabilirsiniz. Şöyle ki, huninin en geniş kısmında basit ve anlaşılabilir bir giriş yapın. Genel bilgilerle konuyu tanıtın. Sonra spesifik bilgilerle huniyi daraltın ve en sonunda çalışmanın sorusunu, hipotezini veya amacını vererek huninin ağzından okuyucuyu makalenin diğer kısımlarına sevk edin.

Bilimsel çalışmalar kurgulanırken genellikle bir bilinen konunun, bilinmeyen 
bir durumda araştırılması yoluna gidilir. Yani, bilinen bir şeyi (örneğin ilaç, sinyal yolağl, biyokimyasal marker gibi) bilinmeyen bir olayda (örneğin fizyolojik durumlarda veya belirli hastalıklarda) araştırılır. Dolayısıyla bu durumda giriş kısmını üç blok halinde yazabilirsiniz. İlk blokta bilinen ile ilgili bilgiler verin, sonraki blokta bilinmeyeni değerlendirin. En son blokta ise bunları birleştirip çalışmanın sorusunu, hipotezini veya amacinı ortaya koyun. Örneğin, ilk paragrafta araştırma konusuyla ilgili genel ve anonim bilgiler verilebilir. $\mathrm{Bu}$ kısmın ilk cümlesine okuyucunun kolaylıkla anlayabileceği en temel veya en genel bir ifadeyle bașlanabilir. $\mathrm{Bu}$ şekilde okuyucu giriș kısmına ve dolayısıyla makaleye angaje edilebilir. İlk bölümün sonlarına doğru ikinci bölümle ilgili ilk bilgiler, ilişkiler ve bağlantılar verilerek bu bölüme yumuşak bir geçiş yapılabilir. Son paragrafta ise her iki blok birleștirilerek çalışmanın amacı veya hipotezi ortaya atılır. Giriş bölümünün sonunda amaç ve hipotez ortaya atıldıktan sonra okuyucuya bu hipotezin nasil test edildiği yani metodolojiyle ilgili genel bir bilgi vererek çalışma sorusunun geçerli bir yöntem ile test edildiği izlenimini verebilirsiniz (Şekil 5).

Sonuç olarak, bir makalenin giriş bölümünü yazarken dikkate alınması gereken hususları şu şekilde sırlayabiliriz:

- Makalenin konusuyla ilgili temel soruları ortaya koyunuz.

- Çalışmanın amacinı somut bir şekilde ifade ediniz.
- Yapılan araștırmanın mevcut bilgilerimize olan katkısını ve bu arada literatürdeki yetersizlikleri ve eksikleri yazınız ve dolayısıyla bir anlamda çalışmanın amacına projeksiyon tutan yaklaşımlar yapınız.

- Giriște sıkıcl, basmakalıp ifadeler ve yoğun kitabi bilgiler vermekten kaçınınız ve giriş kısmını fazla uzun tutmayınız. Ancak daha önceki literatür bilgilerini etraflıca fakat kısaca ortaya koymalısınız.

- Okuyucuların zihinlerini karıștıracak spekülasyonlardan ve ilgisiz söylemlerden kaçınınız.

- Çalıșmanın planlanmasına ait bilgilerle metoda ilişkin kısa bilgiler verilebilir. Ancak bulgulardan bahsetmeyiniz.

- Okuyucuları etkiniz altına alacak düzgün, açık ve literatür diline ait cümle ve ifadeler kullanınız.

- Yabanci dilde yayın yapıyorsanız dil bilgisi kurallarına dikkat ediniz, gerekiyorsa profesyonel yardım alınız.

Makale yazarken ortaya çlkan bir durum da, yazar ile yazılanlar arasında duygusal bir bağın gelişmesidir; şöyle ki, fazla deneyimi olmayan yazarlar, manuskriptin düzeltilmesi yapılırken yazdıklarını silmekte ya da kısaltmakta oldukça tereddüt ederler. 0 cümleleri kurarken ne kadar yoğun emek harcadığını düşünerek kısaltma ve silmelere karşı defansif dururlar. Ancak gereksiz, kafa karıștıran ya da fazla ilgili olmayan konular, mutlaka çıkartılmalıdır ve bu da cesurca yapılmalıdır. 


\begin{abstract}
British Journal of Pharmacology (2004) 143, 431-437

\section{${ }^{1}$ Adnan Levent $\&{ }^{* 1}$ Kansu Büyükafşar Introduction}

One of the most important functions of the pyloureteral complex is to ensure the unidirectional transport of urine from kidney to the urinary bladder. It has been proposed that there might be some putative pacemakers responsible for initiation of peristaltic waves in the renal nelvis as well as ureteral $\begin{array}{lll}\begin{array}{l}\text { smooth muscle (Santicioli } \\ \text { the ureter is innervated by }\end{array} & \mathbf{1 . ~ b l o k} & \begin{array}{l}\text { the other hand, } \\ \text { of afferents that }\end{array}\end{array}$ produce an intense pain following distention of the ureter by ureteral calculi. Electrical field stimulation (EFS) of the ureter also induces pain and muscular hyperalgesia in rats (Cervero, 1994). Furthermore, the implantation of an experimental calculus in rats have caused hyperalgesia and abdominal stretching, a hallmark of visceral pain (Giamberardino et al.,
\end{abstract}

(c) 2004 Nature Publishing Group All rights reserved 0007-1188/04 $\$ 30.00$

www.nature.com/bjp

\section{Expression of Rho-kinase (ROCK-1 and ROCK-2) and its substantial role in the contractile activity of the sheep ureter}

*Author for correspondence; E-mail: kbuyukafsar@mersin.edu.t Advance online publication: 6 September 2004 1995a). Stretching of the ureter may cause the release of prostanoids and tachykinins which amplify ureteral motility (Laird et al., 1997; Lang et al., 2002). The drugs with spasmolytic and/or anti-inflammatory effects can be beneficial in the treatment of renal colic (Giamberardino et al., 1995b). Moreover, installatio ted in a pain-relieving effect in patients (B 2. blok veral mechanisms are proposed in the physionogrearcontroroureteral peristalsis and smooth muscle tone (Santicioli \& Maggi, 1998). Nevertheless, the cellular mechanisms underlying neurogenic and myogenic contractions are not exactly elucidated.

The increase in cytoplasmic free $\mathrm{Ca}^{2+}$ concentration $\left(\left[\mathrm{Ca}^{2+}\right]_{\mathrm{i}}\right)$ was regarded to be the principle mechanism in smooth muscle contraction. Upon activation of calmodulin, $\mathrm{Ca}^{2+}$ activates myosin light chain kinase (MLCK) to phosphorylate the myosin light chain (MLC) to induce smooth muscle contraction (Kamm \& Stull, 1985). However, the studies in which $\left[\mathrm{Ca}^{2+}\right]_{\mathrm{i}}$ and concomitant contractile force were detected have shown that $\mathrm{Ca}^{2+}$ concentration does not always parallel the degree of MLC phosphorylation and subsequent contraction of the muscle. In other words, regulation of MLC phosphorylation and contractile force is independent of changes in $\left[\mathrm{Ca}^{2+}\right]_{\mathrm{i}}$. This is due to a phenomenon, the so-called $\mathrm{Ca}^{2+}$ sensitization (Somlyo \& Somlyo, 1994), raising the possibility that there must be some additional pathways, which can modulate the contractile process at a constant $\left[\mathrm{Ca}^{2+}\right]_{i}$ (Fukata et al., 2001). Indeed, it has been reported that a monomeric small GTP-binding protein, Rho, and its downstream effector, Rho-kinase (ROCK, ROK), play a substantial role in the $\mathrm{Ca}^{2+}$ sensitization (Somlyo ). The activation of heterotrimeric $G$ p 2. blok $\left.\mathrm{G}_{11}\right)$ and $\mathrm{G}_{12 / 13}$ following the stimulation of $\mathrm{G}$ protem-coupled receptors leads to some cellular events. On activation, $\mathrm{G}_{\mathrm{q}}$ or $\mathrm{G}_{11}$ proteins cause phosphatidylinositol 4,5-bis-phosphate hydrolysis to diacylglycerol (DAG) and inositol 1,4,5-triphosphate $\left(\mathrm{IP}_{3}\right)$. However, following the activation of another heterotrimeric $\mathrm{G}$ protein, $\mathrm{G}_{12 / 13}$, the signal is transmitted to the Rho/Rho-kinase pathway (Fukata et al., 2001). This novel pathway provides an alternative vasoconstrictor mechanism, which is independent of $\left[\mathrm{Ca}^{2+}\right]_{\mathrm{i}}$ elevation (Somlyo \& Somlyo, 1994). Indeed, it has been well established that the smooth muscle contraction can be induced also in the absence of an increase in the $\left[\mathrm{Ca}^{2+}\right]_{\mathrm{i}}$ (Bradley \& Morgan, 1987).
It has been reported that Rho/Rho-kinase pathway could be involved in the contractile activity of various tissues such as aorta (Uehata et al., 1997), mesenteric artery (Büyükafşar et al., 2004), ileum (Sward et al., 2000), gastric fundus (Büyükafşar \& Levent, 2003), corpus cavernosum (Büyükafşar \& Ün, 2003), urinary bladder (Wibberley et al., 2003), vas deferens (Büyükafşar et al., 2003) and uterus (Tahara et al., 2002). However, this signalling pathway has not been studied in ureteric smooth muscle. For that reason, first we detected the expression of ROCK proteins of both isoforms by Western blotting in the tissue, and then investigated the functional importance of this enzyme by using its selective inhibitor, (+)(R)-trans-4-(1-aminoethyl)- $N$-(4-pyridyl) cyclohexanecarboxamide dihydrochloride (Ishizaki et al., 2000), in the contrac
phenylephrine and $\mathrm{3}$ 3. blok kinase inhibitor, fasudil in these contractions. Furthermore, possible contribution of the enzyme to the physiological control of spontaneous contractile activity of the tissue was also examined, which would provide a further insight into mechanisms underlying pyeloureteral motility, and so display any physiological and pharmacological relevence of Rho GTPase signalling in the ureteric smooth muscle contraction. Moreover, since decreasing of calculus-induced ureteral motility and stretch may result in a remedy for the visceral pain, we aimed to point out Y-27632 as a possible antispasmodic agent in the ureteral colic.

Şekil 5. Makalenin "Introduction" kısmının yazılmasına bir örnek ${ }^{16}$. Bu örnekte olduğu gibi, "introduction" kısmı 3 blok halinde yazılmıştır. İlk bloğun ilk cümlesine herkesin kolayca anlayabileceği anonim bilgi vererek başlandığına ve böylelikle okuyucunun içeri çekildiğine dikkat edin. Sonra spesifik bilgilerle hipotez noktasına doğru gidildiğini ve son blokta her iki konunun birleştirildiğini, arkasından çalışmanın soru, hipotez veya amacının ortaya atıldığını ve son olarak metoda ait kısa bilgiler verildiğini göreceksiniz. 
8. Materyal ve metodlar (Materials and methods)

$\mathrm{Bu}$ bölüm, diğer araștırmacıların aynı yöntem ve materyalleri kullanarak ilgili çalışmayı tekrar etmelerine olanak sağlayacak şekilde kaleme alınmalıdır. Çalışmada kullanılan her türlü madde, malzeme ile deneylerin planlarına ve protokolüne ilişkin bilgiler verilir. ${ }^{1-9}$ Çalışmanın etik onayı varsa ve isteniyorsa bu bölümde yer verilmelidir.

Makalenin materyal ve metot kısmı, her ne kadar bazen okuyucu tarafından okunmadan atlansa da (belki yöntem hâlihazırda biliniyor olduğu için), bilimsel çalışmaların temel noktalarından biri olan "tekrar edilebilirlik-yinelenebilirlik" için bu bölümün eksiksiz, anlaşılabilir ve kusursuz yazılması gerekmektedir. Materyal ve metodu kaleme alırken dikkate alınması gereken anahtar ifade "yemek tarifi yapar gibi" olmalıdır. Başlıca şunlara dikkat edilmelidir:

- Çalışmada kullanılan tüm materyallere, örneğin deney hayvanı veya insan deneklerine ait bilgiler bulunmalıdır.

- Örneğin yapılmışsa kan, idrar vd. vücut sıvılarının nasıl elde edildiği, nasıl muhafaza edildiği, nasıl santrifüj edildiği vb konuların yazılması gerekir.

- Kullanilan kimyasal maddeler, çözünürlükleri, stabiliteleri, doz/konsantrasyon vd. faydalı bilgiler bulunmalıdır.

- Gerekiyorsa bu maddelerin fiziksel ve kimyasal özellikleri de verilebilir.

- Alet ve edevatlar ile diğer materyallere ait bilgiler bulunmalıdır.

- Deney grupları ve protokolü

- Deneye özgü spesifik bilgilerin tüm detayları

- Metoda ait prensipler ve esaslar (örneğin, nitrit/nitrat tayininin prensibi gibi)

- Verilerin analizi (ölçümler nasıl yapıldı ve nasıl karşıllaştırıldı?)
- Kullanılan test istatistiği (anlamlılık sinırı) ve bu istatistiğin yapıldığ bilgisayar programı

- Çalışmaya dâhil etme/etmeme ölçütleri

- Uluslararası ölçütler (Örneğin Roma IBS kriterleri, hipertansiyon, DSM depresyon ölçütleri, diyabet, obezite sınırları vs.)

- Deneklere ilişkin detaylı bilgiler (tür, cinsiyet, ağırlık, yaş)

- İlaç/madde uygulama yolları vs.

- Örneğin, deneylere neden sadece erkek hastaların veya genç deneklerin alındığı ya da neden genetik obez farelerin vs kullanıldığı belirtilmelidir.

- Temin edilen malzemeler ve cihazların üretildiği veya satın alındığı firma isimleri ile şehir ve ülke isimleri yazılmalıdır. Böylelikle kullanılan cihaz ve malzemelerin uluslararası platformda kabul edilebilirliği okuyucu ve kullanıcıların onayına da sunulmuş olur.

- Her ne kadar pek çok okuyucu materyalmetod kısmını pas geçse de bazıları, özellikle hakem ve editörler çalışmanın materyal ve metodunu dikkatli bir şekilde okurlar ve bu kisımda yapılabilecek hatalara karşı çok duyarlıdırlar. Metodolojide yapılmış bir hata, sonuçları ne kadar parlak olursa olsun o çalışmanın çöpe atılmasına neden olabilir.

- Materyal ve metod kisminin, her ne kadar tartışılabilir olsa da, aktif cümlelerle yazılması istenir.

$\mathrm{Bu}$ bölüm, dergilerin "yazarlara direktifler" ("Instructions to Authors") bölümü iyi okunarak kaleme alınmalı, kullanılan kısaltmalar, ölçüm birimleri, dozkonsantrasyon ifadeleri vd konular, direktiflere uyularak yazılmalıdır $\quad 0.1$ $\mathrm{mM} / \mathrm{L}, 10^{-4} \mathrm{M}, 2 \mathrm{mg} / \mathrm{kg}, 2 \mathrm{mg} \mathrm{kg}^{-1}$ gibi).

Materyal ve metod bölümü okuyucunun daha iyi takip edebilmelerini sağlamak amacıyla alt başlıklara bölünebilir.

\section{Materials and Methods}

\subsection{Subjects/animals}




\subsection{Diabetic protocol}

\subsection{Tissue preparation}

\subsection{Experimental procedure}

\subsection{Drugs and chemicals}

\subsection{Analysis of results and statistics,}

gibi

Bazen çok uzun yer işgal edecek deney protokolleri hem kolay anlaşılabilir olsun diye hem de kısa yer tutsun diye şekilsel olarak da ifade edilebilmektedir (Şekil 6).

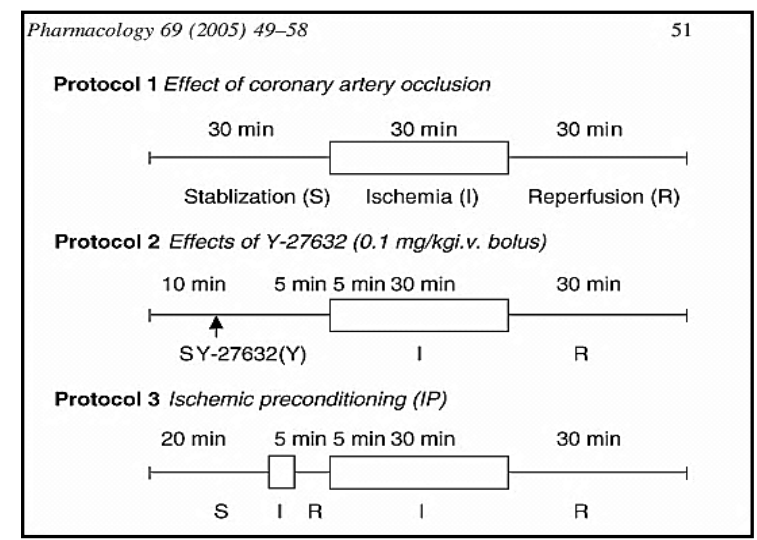

Şekil 6. Materyal ve metodun şekilsel anlatımına bir örnek. ${ }^{17} \mathrm{Bu}$ örnekte yazarlar deney protokolünü şekilsel ifade ederek hem kolay anlaşılır hale getirmişler hem de metnin kelime sayısını azaltmışlardır.

\section{Bulgular (Results)}

Bilimsel bir çalışmada elde edilen bulguların düzgün ve akışkan bir silsileyle ifade edilmesi önemlidir. Bunun için öncelikle tüm bulguların rakamsal verilerden prototip görsel şekillere (örneğin, bar-line grafiklerine ya da tabloya) dönüştürülmesi gerekir. Bunu yaptıktan sonra şekilleri masanızın üstüne yayın. Sonra kuş-bakışı bakarak bir mantık sırası oluşturun. Önce hangi bulgudan başlanacağı ve daha sonra hangi bulgularla devam edileceği, hangi verilerin birlikte gösterileceği ve hangi bulguların tablo, hangi bulguların grafik veya diğer şekillerde ifade edileceğini belirleyin. Bulgular, belli bir mantık silsileyle açık ve yalın olarak yazılmalıdır. Tablo ve grafiklerin seçimi, okuyucunun makale takibini kolaylaştıracak şekilde anlaşılır olmalıdır. Tablo ya da grafik olarak verilmeyecek kadar önemsiz bulgular (daha önce başka makalelerde gösterilmiş olduğu için veya standart bir uygulamanın doğruluğunu ortaya koymak için yapılmış da olabilir) sayısal değerler halinde, ortalama \pm standart hata (ya da sapma) şeklinde metin içinde verilebilir. Orijinal (ilk sizin gösterdiğiniz) bulgularınızı mutlaka șekillerle veya tablo olarak gösteriniz. İkincil verileri (circumstantial data) şekil halinde ifade etmek zorunda değilsiniz. Önemine göre metin içerisinde de bahsedebilirsiniz.

Sonuç olarak "Bulgular" kısmı kaleme alınırken şu hususlara dikkate edilmelidir:

- Yazım tarzı sade, süslemesiz ve kısa olmalıdır.

- Direk ifadelerle net olarak yazılmalıdır.

- Anlamlı olmayan değişmeleri ifade ederken "azalttı" ya da "artırdı" yerine, sadece anlamlı değişmeler için bu ifadeler kullanılmalıdır.

- Bulgular, detaylı ve karşlaştırılabilir göstermek için, genellikle tablo, grafik vs gibi görsel sunum șekilleri ile ifade edilmelidir. Ancak hâlihazırda şekillerle (tablo, grafik vs.) gösterilen bulgular, metin içerisinde çok uzun uzadıya yazılmamalıdır.

- Bazen bulgularin rasyonelitesi de yazılabilir (bu tarz deney serilerinin neden icra edildiği, neyi göstermek amacıyla yapıldığı gibi ancak tartışma formatında değil). Örneğin, "Nöronal sodyum kanalların elektriksel uyarı ile oluşan cevaplara katkısını araştırmak amaciyla sodyum kanal blokörü tetrodotoksin varlı̆̆ında elektriksel uyarı yapıldı..." gibi. Ya da "Hipertansiyona adrenerjik sistemin katkısını araştırmak amaciyla deneklerin kaninda adrenalin/noradrenalin metabolitleri olan vanilinmandelik asit ve metoksihidroksi feniletilen glikol düzeyleri ölçüldü" gibi. Ancak bulguların yorumlanması yani neyi ifade ettiği, ne anlama geldiği, güncel bilgilerle olan karşılaştırılması vs gibi konular, tartışma kısmına bırakılmalıdır.

- Çoğunlukla deneylerde uygulanan yöntemin işe yaradığının ispat edilmesi gerekir. Örneğin, diyabet protokolü oluşturulmuşsa deneklerin diyabete 
girdiğinin bir şekilde kanıtlanmalıdır. $\mathrm{Bu}$ gibi durumda elde edilen bulgunun müstakil bir şekil yerine metin içinde zikredilmesi daha doğru olur zira elde edilen bulgu orijinal bir bulgu değildir fakat kanitlanması gereken bir durumdur. 0 bakımdan metin içinde sayısal olarak verilebilir. Örneğin, streptozosin adlı kimyasal madde, deney hayvanlarında şeker hastalığ oluşturmaktadır ancak bunun kanıtlanması gerekir. $\mathrm{Bu}$ da, genellikle kan şeker düzeyinin gösterilmesiyle olur. Aşağıdaki örnekte olduğu gibi diyabet bulgusu metin içinde verilmiştir (Şekil 7).

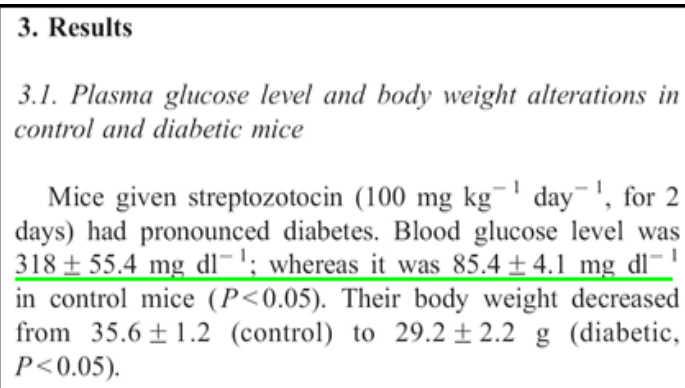

Şekil 7. Bulguların rakamsal olarak metin içinde gösterilmesine ilișkin bir örnek ${ }^{18}$. Bu örnekte altı çizilen bulgular, ilk kez yazarlar tarafından elde edilmediği için ayrı bir grafik ile göstermek yerine bulguyu metin içinde sayısal olarak vermişlerdir. Ayrıca yapılan uygulamanın işe yaradığını da okuyucuya göstermek gerekir.

- Bazen çalışma konusu ile direkt ilişkili olmayan ancak tamamlayıcı bulgular veya uygulama sonucunda gerçekleşeceği genellikle öngörülen veriler, șekil ile gösterilmeksizin ifade edilebilir. Ayrıca, kalabalık bir veri seti ile okuyucunun dikkatini dağıtmamak, sadece önemli bulgulara yoğunlaşmak amacıyla da yapılabilir. Örneğin, elektriksel uyarı ile oluşturulan ileum kasılmaları tetrodotoksin ile ortadan kalktı (veri gösterilmemiştir, "data not shown"), gibi (Șekil 8). levels (Figs. 2-4). Western blot analysis also confirmed the restorative effect of Y-27632 (Fig. 5). The Rho-kinase inhibitor alone had no effect on the pulmonary histopathology at either dose (data not shown), and neither did it significantly change serum and tissue oxidative and nitrosative stress markers (data not included).

Şekil 8. $\quad$ Bulguların sayısal olarak gösterilmemesine (gizlenmesinegömülmesine) ait bir örnek ${ }^{12}$. Bu örnekte yazarlar okuyucunun dikkatini dağıtmamak ama okuyucu için önemli olacağını düşündükleri bulgularını, veri göstermeksizin paylaşmışlardır (altı çizili ifadeler).

- Sayısal olarak değerlendirilmeyen gözleme dayalı bulgular, istenirse kısaca yazılabilir (Şekil 9). Örneğin,

nounced acute lung damage (Fig. 1). The lung tissue was much darker red in the oleic acid group than in the other groups. Furthermore, an increase in congestion, neutrophil infiltration and even derangement of pulmonary architecture were observed under light microscopy (grade 3).

Şekil 9. Gözlemsel bulguların paylaşılmasına ait bir örnek. ${ }^{12} \mathrm{Bu}$ örnekte yazarlar, deney/uygulama sırasında yapmış oldukları gözlemleri okuyucu ile paylaşmak istemişlerdir (altı çizili cümle). Bu bilgi, paylaşılmasa da olurdu ama yazarlar deney esnasında gördükleri değișiklikleri okuyucu ile paylaşarak bu tür deneylerin başkaları tarafından tekrarlanması durumunda, benzer değişimleri gördüklerinde doğru yolda oldukları izlenimi edinebilirler.

- “Grafik 2'de görüldüğü gibi fasudil, lökosit migrasyonunu inhibe eder", yerine "Rhokinaz enzim inhibitörü, fasudil, lökosit migrasyonunu anlaml bir şekilde inhibe etti $(P<0.05$, Sekil 2 gibi)." yazılması daha doğrudur.

- Bulgular, geçmiş zaman (past tense) diliyle genellikle aktif ("active voice"), bazen yazarların tarzına göre pasif ("passive voice") olarak da yazılır.

\section{Şekiller (Figures)}

Çalışmanın bulguları çeșitli görsel sunum şekilleriyle ifade edildiğinde daha 
etkili ve anlaşılabilir olmaktadır. Ayrıca makale içinde daha küçük yer işgal ederler. $\mathrm{Bu}$ da istenen bir durumdur. Bulgular, bar ("bar"), çizgi ("line") ya da pasta ("pie") grafikleri şeklinde ifade edilebileceği gibi tablo, resim ya da yazarlar tarafından oluşturulmuş bir çizim şeklinde de olabilmektedir.

Bar grafikleri, genellikle iki veya daha fazla (fakat çoğunlukla 5-6'yı geçmeyen) ortalamaları bir arada karşılaştırmak için kullanılmalıdır (Şekil 10).

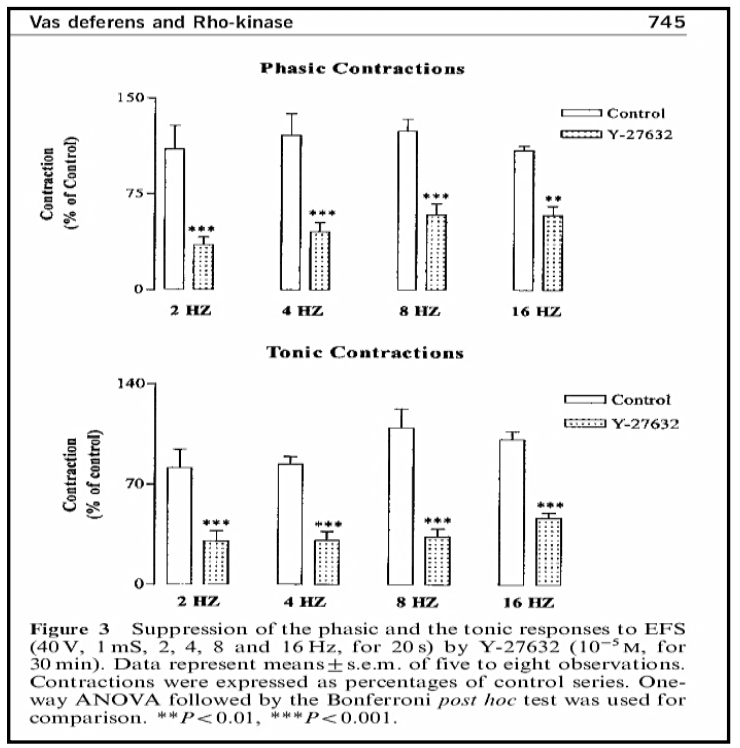

Şekil 10. Bar grafiğin seçilmesine ait bir örnek. ${ }^{19} \mathrm{Bu}$ örnekte yazarlar okuyucunun takibini kolaylaştırmak ve iki ortalama arasındaki farkı net bir şekilde göstermek için verilerini bar grafiği ile göstermişlerdir.

Çizgi ("line") grafikler ise, zamansal değişmeleri veya çok fazla sayıda uygulamaları birlikte ifade ederken seçilmelidir (Şekil 11).

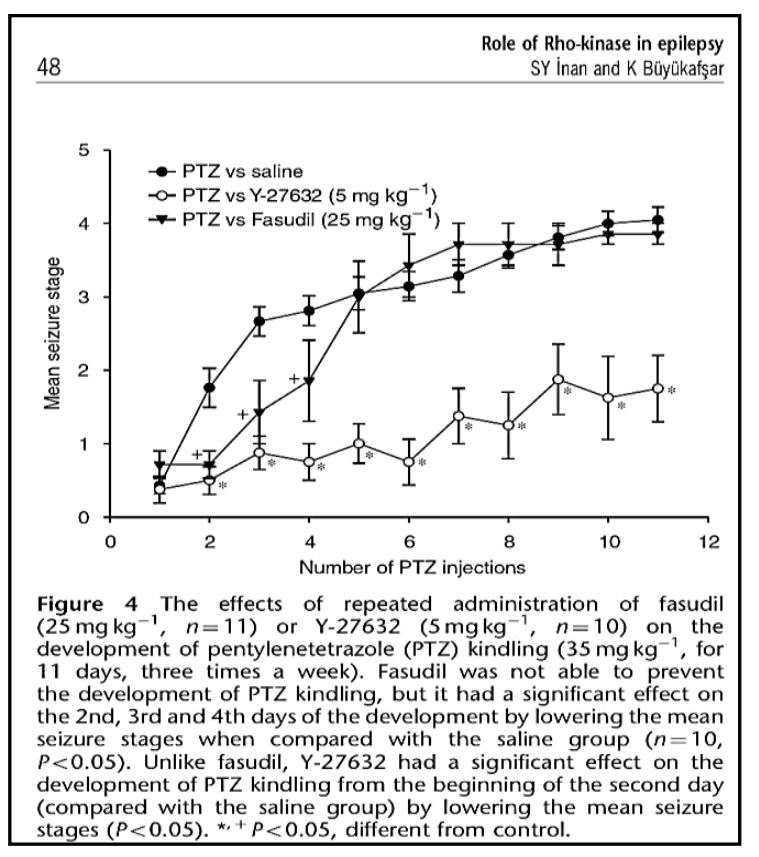

Şekil 11. Çizgi grafiğin seçilmesine ait bir örnek. ${ }^{20} \mathrm{Bu}$ örnekte yazarlar tekrarlayıcı ve zamansal boyutu olduğu için bulgularını "line" grafiği șeklinde tercih etmişlerdir.

Pasta grafikleri ("pie graph") daha seyrek kullanılmaktadır. Genellikle bir bütünde oranları göstermek için tercih edilir (Şekil 12).

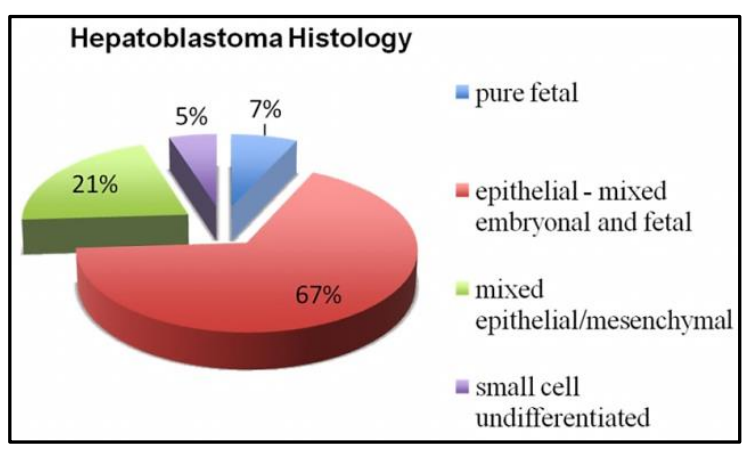

Şekil 12. Pasta grafiğin seçilmesine bir örnek. ${ }^{21} \mathrm{Bu}$ örnekte yazarlar, dağılımları bir bütün içinde \% olarak göstermek için pasta grafiğini tercih etmişlerdir. Sayıların toplamı, görüldügü gibi 100 etmektedir. Seyrek de olsa bu tür ortalamalara standart hata veya sapma da eklenebilmektedir.

Tablolar ise, bar veya çizgi grafik şeklinde ifade edilemeyecek kadar fazla verileri bir bakıșta değerlendirmek için veya birbirinden farklı olan uygulamaları tek bir gösterimle ortaya koymak ya da yardımcı verileri göstermek için tercih edilmelidir (Şekil 13). 


\begin{tabular}{|lcccccc|}
\hline \multicolumn{7}{c|}{ Table 1. Clinical characteristics of patients with various cerebrovascular diseases } \\
\hline & Anterior ICAS & Posterior ICAS & ECAS & MMD & Control & $P$ Value \\
\hline Number of patients, n (\%) & $43(19.5)$ & $61(27.6)$ & $12(5.4)$ & $5(2.3)$ & $100(45.2)$ & \\
Age (y), mean \pm SD & $70.6 \pm 14.1$ & $75.1 \pm 9.2$ & $73.8 \pm 11.7$ & $46.4 \pm 19.3$ & $68.8 \pm 15.8$ & .0040 \\
Range (y) & $30-89$ & $46-94$ & $55-90$ & $14-62$ & $14-91$ & .14 \\
Female, n (\%) & $25(58.1)$ & $20(32.8)$ & $5(41.7)$ & $2(40.0)$ & $47(47.0)$ & \\
Underlying diseases, n (\%) & & & & & & .54 \\
Hypertension & $33(76.7)$ & $53(86.9)$ & $9(75.0)$ & $4(80.0)$ & $76(76.0)$ & .14 \\
Diabetes & $12(27.9)$ & $29(47.5)$ & $3(25.0)$ & $1(20.0)$ & $31(31.0)$ & .38 \\
Dyslipidemia & $25(58.1)$ & $29(47.5)$ & $5(41.7)$ & $2(40.0)$ & $40(40.0)$ & .14 \\
Ischemic heart diseases & $4(9.3)$ & $7(11.5)$ & $1(8.3)$ & $0(.0)$ & $2(2.0)$ & .64 \\
Arteriosclerosis obliterans & $2(4.7)$ & $2(3.3)$ & $0(.0)$ & $0(.0)$ & $1(1.0)$ & .33 \\
Smoking, n (\%) & $13(30.2)$ & $23(37.7)$ & $6(50.0)$ & $0(.0)$ & $37(37.0)$ & $29(29.0)$ \\
Alcohol, n (\%) & $8(18.6)$ & $15(24.6)$ & $5(41.7)$ & $1(20.0)$ & $29)$ \\
\hline
\end{tabular}

Şekil 13. Tablo seçimine ait bir örnek. ${ }^{22} \mathrm{Bu}$ örnekte yazarlar pek çok veriyi derli toplu göstermek için tablo kullanmışlardır.

Bazı yazarlar tablo ile veri gösterme işini fazlasıyla abartabilmektedir. Rahatlıkla bar veya line grafikleriyle gösterebilecekleri verileri de tablo ile göstermektedirler. Aslında sayısal verilerden çok, görsel şekillerin tercih edilmesi daha doğru olur. Ancak, verilerin tablo, bar veya çizgi şeklindeki ifade edilmesi biraz da yazarların tarziyla ilgilidir.

Orijinal traseler (orijinal kayit görüntüleri, örneğin EKG kaydı gibi), şekillerden biri olarak da gösterilebilir. Bu durumda traseyi gösteren şekilde, okuyucunun rakamsal takibi için bir cetvel (skala, zaman, ağırlık, amplitüd vs) bulunmalıdır (Şekil 14).

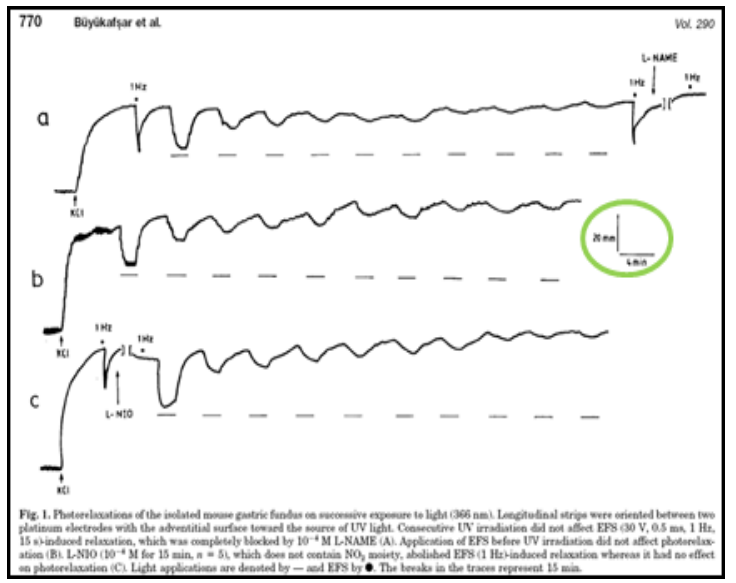

Şekil 14. Grafik içinde iki boyutu (zamanmekân) yansitan cetvelin gösterilmesine bir örnek. ${ }^{23} \mathrm{Bu}$ grafikte yazarlar, oluşan cevabın büyüklüğünü ve zaman içindeki seyrini gösterebilmek için elips içinde gösterildiği gibi bir cetvel eklemişlerdir.
Histopatolojik incelemeler, ameliyat tekniği veya hastaya ait görüntüler gibi, görselliğin okuyucular için daha faydalı olacağı düşünülen bulgular, fotoğraf şeklinde gösterilebilir (Şekil 15).

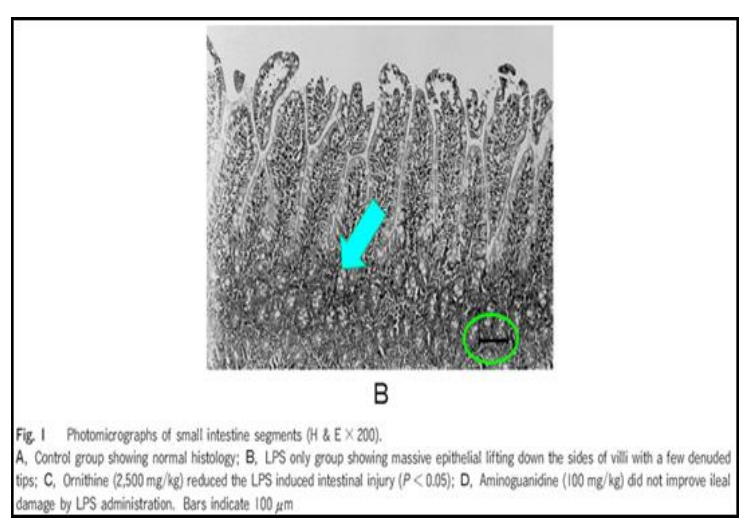

Şekil 15. Grafik içinde önemli noktalara vurgu yapmak için işaretlerin kullanılmasına ait bir örnek. ${ }^{24} \mathrm{Bu}$ grafikte yazarlar ilgili yere vurgu yapmak için ok işareti ve mikroskopik görüntünün büyüklüğünü karşılaştırmak için uzunluk barı eklemişlerdir.

Bazen yazarlar yaptıkları bir takım uygulamaları kendileri tarafından oluşturulmuş bir çizim ile de ifade edebilirler (Şekil 16). 


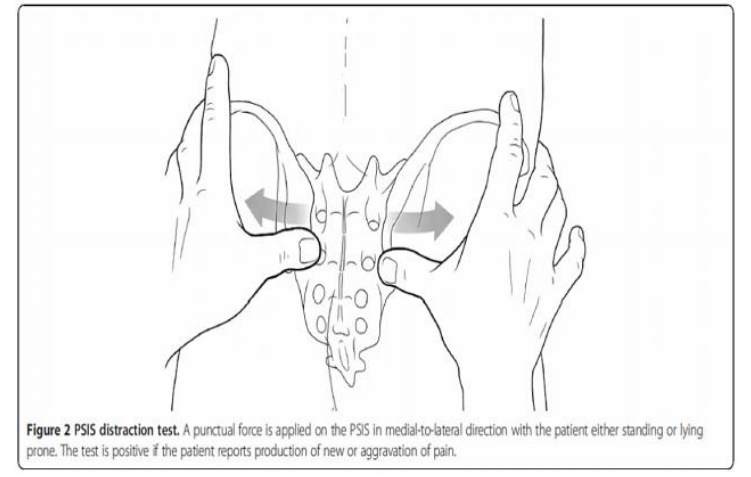

Şekil 16. Bulgu veya uygulamaların yazarların bizzat kendi çizimleriyle göstermelerine bir örnek. ${ }^{25}$ Yazarlar bu örnekte tanıda kullandıkları bir manevrayı (PSIS distraksiyon testini) ve nasıl yaptıklarını kendi çizimleriyle ifade etmişlerdir.

\section{Şekil Altlar (Figure Legends)}

Şekil altları yazılırken uyulması gereken temel nokta, okuyucunun metne bakmasına gerek kalmaksızın şeklin anlaşılmasının sağlanmasıdır. Şekil altı, kısa başlık, materyal-metod ve bulgu, içerebilir. Gerekiyorsa çarpıcı verilere vurgu yapılabilir. Varsa istatistiksel anlamlılık değerleri, kullanılan test istatistiği, denek sayısı, büyütme oranı (x100 vs), verilerin analiz yöntemi vs yazılmalıdır.1-9 (Șekil 17).

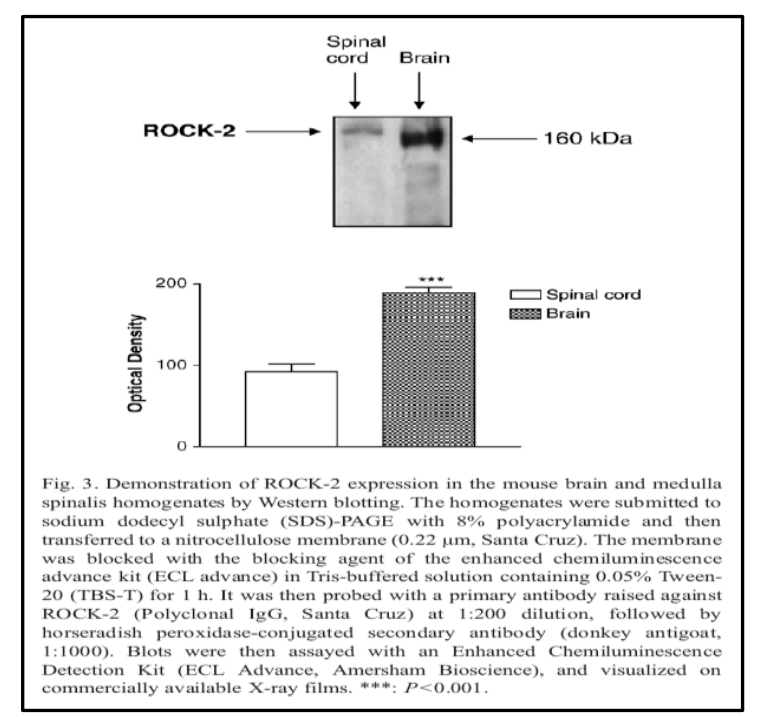

Şekil 17. Şekil altının yazılmasına bir örnek. ${ }^{26} \mathrm{Bu}$ grafikte yazarlar okuyucunun makale takibi kolaylaştırmak ve sürekli makale metnine dönüp bakmasını önlemek amacıyla bilinçli olarak şekil altını uzun tutmuşlardır.

\section{Tartışma (Discussion)}

Yazılmasında en çok güçlük çekilen makale bölümü olarak bilinir. Oysa literatüre hâkim olunduktan sonra yapılması gereken şey, mevcut bulguları bu bilgiler ışığı altında yorumlamak, tartışmak ve daha önce yayımlanmış bulgularla karşılaştırmaktır.1-9 Fazla deneyimi olmayan yazarlar tartışma bölümünü yazarken çoğunlukla çalışma bulgularını tekrar ederler. Ancak bulguların ne anlama geldiği, neyi yansıttığı ortaya konulmalıdır. Bazen de aşırı miktarda kitabi bilgiler verilir ve genellemeler yapılır, bütün bunlardan kaçınmak gerekir. ${ }^{1-9}$ Çalışmadan elde edilen her bir bulgu, etraflica ve tatmin edici bir şekilde objektif olarak tartışılmalıdır ancak bu tartışmanın da bir sınırı olmalıdır. Bazen yazarlar tartışma bölümünü yazarken kapsamı çok geniş tutabilirler. $\mathrm{Bu}$ da okuyucunun tartışmaya odaklanmasını ve konuyu anlamasını engelleyebilir. Tartışma bittikten sonra bu kısmın ilgili kişililere değerlendirmek üzere okutulmasında fayda vardır. Böylelikle, diğer kişilerin eleştirileri de alınmış olur. Bir makalenin tartışma kısmını yazarken dikkat edilmesi gereken noktalar şöyle sıralanabilir:

- Tartışmanın ilk cümlesine, kısaca çalışmada nelerin yapıldığı, neyin araştırıldığı ve hangi önemli sonuçların elde edildiğinin yazılmasıyla başlanabilir. $\mathrm{Bu}$, metin içerisindeki basmakalıp ve sıkıcı bulgu tekrarı anlamına gelmez. $\mathrm{Bu}$ arada tartışmanın başında çalışmanın hipotezine/amacina tekrar vurgu yapılabilir (Şekil 18).

- Sonra her bir bulguyu mevcut literatür bilgileri ışığı altında etraflıca tartışınız ve yorumlayınız.

- Genel olarak literatüre hâkim olunmalı ve araştırma konusuyla ilgili mümkün olan en derin özel bilgilere sahibi olunmalıdır.

- Bulgularla uyumlu literatür bilgileri veriniz, böylelikle bulgularınızı güçlendiriniz. Ancak, varsa karşıt görüşlere de yeterince yer verilmelidir. Böylece objektif bir tartışma yapmış olursunuz. Bulgularınızın doğruluğundan eminseniz onları mutlaka güçlendiriniz, literatür desteği veriniz. 
- Yaptığınız çalışmanın olası zayıflıklarını ve bunlara yönelik varsa çözüm önerilerini yazınız. Örneğin, "Amperometrik yöntem çok düşük NO düzeylerini bile ölçebilmektedir. Ne var ki, bu yöntemde kullanılan probun reaksiyon süresi uzundur. $B u$ durum, anlık değişmelerin ölçüldüğü deneylerde sorun oluşturmuş olabilir. Böyle bir ihtimalin bertaraf edilmesi için daha kısa reaksiyon süreli probların geliștirilmesi gerekir." gibi.

- Materyal/metodla ilgili rasyonaliteler yazılmalıdır. Yani alternatifleri varken bir kimyasal maddenin ya da ameliyat tekniğinin neden kullanıldığ tartışılabilir. Örneğin, kısa etkili ilaç yerine neden uzun etkili ilaç kullanıldığına dair rasyonellikler ya da açık cerrahi yerine neden endoskopik cerrahinin uygulandığına dair nedensellikler tartışılarak verilmelidir (Şekil 19).

- $\mathrm{Az}$ da olsa kanıtsız çıkarımlara ("postulation") veya spekülasyonlara ("speculation") da yer verebilirsiniz (Şekil 20).

- Yanlış yargılara varılmaması için azami dikkat ve özen gösterilmelidir. Gerçeklerle, deney sonunda ulaştığınız yargılar birbiriyle örtüşmeyebilir. Aslında elde edilen bulguları biz anlamlandırıyoruz. $\mathrm{Bu}$ yüzden yanlıș anlamlandırma ihtimaline karşı dikkatli olunmalıdır.

- Tartışma geniş zaman (simple present, present perfect tense) diliyle yazllır. Başka yazarlara ait genelleşmiş bilgileri kullanırken daha ziyade geniş zaman, kendi bulgularınızı ifade ederken geçmiş zaman kullanınız. Bu bölümde olasılıklar, spekülasyonlar, karşıt görüşler ve ihtimaller sık kullanıldığ ifade eden cümleleri, "modals" (cancould, may-might, should vs) formatında kaleme alabilirsiniz (Şekil 19, 20).

- Tartışma sıkıcı olmamalı, tam tersine keyifle okunabilmelidir. Çok uzun tartışmalardan ve uzun kitabi bilgilerden sakınınız.

- Tartışma, mutlaka güncel bilgiler dikkate alınarak yazılmalıdır.

\begin{abstract}
Discussion
In the present study, we have investigated two specific Rho-kinase (ROK $\alpha$ ) inhibitors, Y-27632 and fasudil, on the contractile responses to $\mathrm{CCh}, \mathrm{KCl}$, and EFS. Moreover, we have also examined the possible relaxant activity of these compounds. We have, for the first time, tested whether the ROK $\alpha$ inhibitor, Y-27632, may have a modulatory effect on acetylcholine release from the myenteric plexus of the mouse gastric fundus.

Members of the Rho GTPase family are regulatory proteins involved in signalling between cell surface receptors and the contractile apparatus (actin cytoskeleton) [10]. ROK $\alpha$ plays an important role in myosin

\section{DISCUSSION}

IN THIS FIRST-IN-HUMAN STUDY, THE TOPICAL RHO KI nase inhibitor AR-12286 demonstrated a dose-related ocular bynotensive efficacy in patients with elevated IOP. All 3 concentrations of AR-12286 produced statistically and clinically significant reductions in mean IOP relative to diurnally adjusted baseline, with peak effects occurring 2 to 4 hours after acute or chronic note in the present study. Only 1 patient was discontinued for an adverse event-moderate hyperemia on day 4 at the $0.25 \%$ concentration. The only adverse event of note was conjunctival hyperemia. This is consistent with the nharmacologic features of Rho kinase inhibitors and was renorted previously for this class when andied tonically to the eve. ${ }^{17}$ AMERICAN JOURNAL OF OPHTHALMOLOGY NOVEMBER 2011 (Discussion

4. Discussion

The main findings of the present study are that ROK $\alpha$ is expressed in the mesenteric artery and contributes to the control of perfusion pressure, that endothelium removal does not change the vasodilator effect of Y-27632 and finally that receptors for endothelin-1 and phenylephrine are associated with Rho/Rho-kinase signalling to a different extent.

It has been reported that alteration of Rho-kinase-mediated regulation of vascular tone is a possible cause of increased vascular resistance (Wettschureck and Offermanns, 2002). Therefore. maninulation of this nathway with snecific nharmacological tools. including $\mathrm{Y}-27632$. mav control elevated blood nressure. In this study, both Rho-kinase inhibitors produced vasodilatation which was not dependent on an intact endothelium. There was no potency and efficacy

Discussion

This study examined the role of fiber sunplementation in patients under effective therapy with lipid-lowering drugs. It has been reported that consumption of soluble fibers promotes a moderate effect in lowering cholesterol in hypercholesterolemic patients [20,21]. However, the literature is scarce in relation to the benefit of fibers added to therapy in patients taking effective lipid-lowering agents. Our study has shown that no further reduction was achieved in total cholesterol, LDL-cholesterol, and triglycerides when fibers were added to an effective therapy. However, fibers seemed to act synergistically with ezetimibe, reducing phytosterolemia, at the recommended dose for total ( $25 \mathrm{~g})$ and soluble fibers $(6 \mathrm{~g})$ intake [1]
\end{abstract}

Şekil 18. Makalenin tartışma kısmının yazılmasına ilişkin çeşitli örnekler. ${ }^{27,28,29,30} \mathrm{Bu}$ örneklerde bir makalenin tartışma kısmına nasıl birden fazla şekilde giriş yapılabileceği gösterilmektedir. Altı çizili cümlelere özellikle dikkat ediniz. 
Tartışma spekülasyonlara ve postülasyonlara (kanıtsız çıkarımlar) yer verilebilir. Ancak çalışmanın bütünlüğünü bozmadan ve okuyucuların ilgisi çok dağıtmadan yapılabilir (Şekil 19).

One of the most interesting facets of the present study is
the filling up of photosensitive NO store by long-term EFS.
The refilling effect probably resulted from NO release be-
cause prolonged incubation of L-NA markedly inhibited EFS-
elicited relaxation. This is the first direct evidence that en-
dogenous NO can replenish the photosensitive materials
store. The physiological importance of this phenomenon
seems worthy of being explored because it might point out a
conservation mechanism for NO in the target (smooth mus-
cle) cell. Further, it has been known that NO can react with

Şekil 19. Tartıșma bölümünde spekülasyonlar ve postülasyonların ifade edilmesine ait bir örnek. ${ }^{23} \mathrm{Bu}$ örneklerde altı çizili cümlelerle hem çalışmanın güçlü taraflarına dem vurulmakta hem de spekülasyonlara ve önerilere yer verilmektedir.

Tartıșmanın son cümlesi ya da paragrafı, ilgili çalıșmanın dünya bilimine ne kazandırdığının yazılmasıyla bitirilebilir. Ya da nihayetinde bu çalışmanın tek bir cümle ile sonucunun ne olduğu yazılabilir. $\mathrm{Bu}$ bakımdan "In conclusion" ya da "Conclusively" veya "Taken together" ile başlayarak çalışmanın sonucu bilim dünyasina duyurulur. Genellikle çalışmaların tek bir çıkarımı olur ama bazen birden fazla sonuç da verilebilir (Şekil 20).

\footnotetext{
In conclusion, AR-12286 provided clinically and statistically significant ocular hypotensive efficacy in

In conclusion, the mouse vas deferens expresses ROCK-2 protem, and this enzyme can mediate EFS-, Phe-, ATP- and $\alpha, \beta$-methylene ATP- as well as $\mathrm{KCl}$-induced contractile responses. Another deduction from this studv is that the use of Rho-kinase inhibitors in the treatment of erectile dysfunction may cause an impaired ejaculation, as EFS-evoked sympathetic contractions are known to be involved in the physiological ejaculation (Sato et al., 1991; Kihara et al., 1997; de Groat \& Booth, 1980)
}

Şekil 20. Tartışmanın sonuç ("conclusion") kısmının yazılmasına örnekler.19,28 $\mathrm{Bu}$ örneklerde hemen her tartışmanın tipik son cümlelerini görmektesiniz.
Bazen çalıșmayla ilgili sınırlamalar, eksiklikler veya zayıf noktalar verilebilir (Şekil 21).

Limitations of the Studv
The main limitation of our study was its small sample
size: our findings need to be validated in a larger patient
population. Also, our patients were relatively healthy
and had minimal cardiac risk factors, so it is possible
that they did not have clinically appreciable atheroscle-
rotic lesions and that the release of MMP-13 into the
blood was minor. Nevertheless, the similarity between
MMP-13 levels in all patients before and after rosuva-
statin therapy supports the reliability of our results. In
addition, we did not compare our results with those of
a sex- or age-matched control or placebo-treated group
of patients, so our findings should be interpreted with
careful consideration. We also did not examine hs-CRP
levels, which might have provided additional informa-
tion about the clinical usefulness of MMP-13 analysis.
Finally, the duration of the study was a brief 4 weeks, in
accordance with the study protocol. Longer monitoring
might have enabled the examination of other endpoints,
such as disease progression, and their effects on MMP-
13 or TIMP-1 levels.

Şekil 21. Tartışma kısmında çalışmayla ilgili sinırlamalar, eksiklikler veya zayıf noktaların yazılmasına ait bir örnek. ${ }^{31} \mathrm{Bu}$ örnekte ilgili çalıșmanın eksikliklerine ve bunların çözüm önerilerine değinildiğini göreceksiniz.

\section{Teșekkür-Bildiri (Acknowledgement)}

$\mathrm{Bu}$ bölümde çalışmaya yardım ve katkı yapmış ancak yazar olabilme ölçütlerini yerine getirmemiş kişilere ayrıca çalışmaya maddi destek veren araştırma fonları, kurum ve kuruluşlara teşekkür edilir (Şekil 22). Maalesef ülkemizde yazarlar bu bölümü yeterince etkili kullanamamaktadırlar. Ancak son zamanlarda araştırma fonları ile proje yürütücüsü arasında yapılan protokollere göre desteğin belirtilmesi zorunlu hale gelmiştir. 
Acknowledgements

This work has been supported by the grants from the Mersin University Scientific Projects Unit (K.B./BAP.TF.DTB/2005-2) and the Turkish Academy of Sciences (K.B./TÜBA-GEBIP/ 2002-1-5).

Şekil 22. "Acknowledgement" kısminın yazılmasına bir örnek. ${ }^{27} \mathrm{Bu}$ örnekte yazarların ilgili kişilere ve çalışmayı fonlayan kuruluşlara teşekkürlerini görmektesiniz.

\section{Kaynaklar (References)}

Kaynak gösterimi konusunda yazarlar genellikle pek özenli davranmazlar oysa atıfta bulunulan kaynakların doğruluğu o çalışmanın gücünü artırır. Konuyla ilgili son makaleler takip edilmeli ve "manuskript" gönderilmeden önce bir kez daha bu açıdan kontrol edilmelidir. Bir makalede kullanılacak kaynakları seçerken şunlara dikkat edilmelidir: ${ }^{1-5}$

1. Atıfta bulunulan çalışma hakikaten 0 konu hakkında önemli ve doğru bilgiler veriyor mu?

2. Hipotezi geçerli mi?

3. Yöntemi ve uygulanması doğru mu?

4. Makale sonuç olarak dengeli ve tutarlı $\mathrm{mi}$ ?

\section{Kaynaklar}

1. Plaxco K.W. The art of writing science. Protein Science 2010;19:2261-2266.

2. Day R.A. Bilimsel makale nasıl yazllır, nasıl yayımlanır? Çeviri: Aşkar Altay G., TÜBITAK yayınları, 10 . baskı. Şener Basım Sanayii. 1996;1-233.

3. Huth, E.J. Guidelines on authorship of medical papers. Ann Internal Med 1986;104:269-274.

4. Instructions to authors. British Journal of Pharmacology. Erişim tarihi 12.06.2017. http://www.nature.com/bjp/index.html

5. 8. International Committee of Medical Journal Editors. Uniform requirements for manuscripts submitted to biomedical journals. Can Med Assoc J 1994;150:147154.
6. Bostancı K., Yüksel M. Araştırma nasıl yapılır, makale nasıl yazılır? Türk Gögüs Kalp Damar Cerrahisi Dergisi 2005;13(3):298-302.

7. Kotsis, S.V., Chung K.C. How to submit a revision and tips on being a good peer reviewer. Plastic \& Reconstructive Surgery 2014;133:958-964.

8. Gülpınar Ö., Güçlü A.G. How to write a review article? Derleme makalesi nasıl yazılır? Turkish Journal of Urology 2013;39(1):44-48.

9. Hoogenboom B.J., Manske R.C. How to write a scientific article. The International Journal of Sports Physical Therapy 2012; 7(5):512-517.

10. Sahan-Firat S., Tiftik R.N., Nacak M., Büyükafșar K. Rho kinase expression and its central role in ovine gallbladder contractions elicited by a variety of excitatory stimuli. Eur $J$ Pharmacol 2005; 528(1-3):169-175.

11. Buyukafsar K., Nelli S., Martin W. Formation of nitric oxide from nitroxyl anion: role of quinones and ferricytochrome c. $\mathrm{Br} \quad J$ Pharmacol 2001;132(1):165-172.

12. Köksel O., Yildirim C., Tiftik R.N., Kubat H., Tamer L., Cinel L., Kaplan M.B., Değirmenci U., Ozdülger A., Büyükafşar K Rho-kinase (ROCK-1 and ROCK-2) upregulation in oleic acidinduced lung injury and its restoration by Y-27632. Eur J Pharmacol 2005;510(12):135-142.

13. LeMaire S.A., Price M.D., Green S.Y., Zarda S., Coselli J.S. Results of open thoracoabdominal aortic aneurysm repair. Ann Cardiothorac Surg 2012;1(3):286-292.

14. Kurt A.H., Tiftik R.N., Un I., Ulker S., Buyukafsar K. G protein-coupled estrogen receptor1 (GPER1) may mediate Rho-kinase (ROCK-2) upregulation in coronary endothelial cells. Endocr Regul 2013;47(2):75-84.

15. Shimokawa H., Takeshita A. Rho-kinase is an important therapeutic target in cardiovascular medicine. Arterioscler Thromb Vasc Biol 2005;25(9):1767-1775. 
16. Levent A., Büyükafsar K. Expression of Rho-kinase (ROCK-1 and ROCK-2) and its substantial role in the contractile activity of the sheep ureter. $\mathrm{Br} J$ Pharmacol 2004;143(3):431-437.

17. Demiryürek S., Kara A.F., Celik A., Tarakçioğlu M., Bağci C., Demiryürek A.T. Effects of Y-27632, a selective Rho-kinase inhibitor, on myocardial preconditioning in anesthetized rats. Biochem Pharmacol 2005;69(1):49-58.

18. Büyükafșar K., Un I. Effects of the Rhokinase inhibitors, Y-27632 and fasudil, on the corpus cavernosum from diabetic mice. Eur J Pharmacol 2003 11;472(3):235-238.

19. Büyükafşar K., Levent A., Ark M. Expression of Rho-kinase and its functional role in the contractile activity of the mouse vas deferens. $\mathrm{Br} J$ Pharmacol 2003;140(4):743-749.

20. Inan S., Büyükafşar K. Antiepileptic effects of two Rho-kinase inhibitors, Y27632 and fasudil, in mice. $\mathrm{Br} J$ Pharmacol 2008;155(1):44-51.

21. Wiederkehr J.C., Celho I.M., Avilla S.G., Wiederkehr B.A., Wiederkehr H.A. Liver Tumors in Infancy 2013;18:423-459.

22. Shinya Y., Miyawaki S., Imai H., Hongo H., Ono H., Takenobu A., Nakatomi H., Teraoka A., Saito N. Genetic Analysis of Ring Finger Protein 213 (RNF213) c. $14576 \mathrm{G}>\mathrm{A}$ in Intracranial Atherosclerosis of the Anterior and Posterior Circulations. J Stroke Cerebrovasc Dis 2017;26(11):2638-2644.

23. Büyükafşar K., Demirel-Yilmaz E., Göçmen C., Dikmen A. Depletion and restoration of the putative photosensitive materials store yielding nitric oxide in the isolated mouse gastric fundus. $J$ Pharmacol Exp Ther 1999;290(2):768-773.

24. Dirlik M., Büyükafşar K., Cinel I., Cinel L., Caglikülekçi M., Tamer L., Aydin S., Oral U. Effect of ornithine on the ileal histology, nitric oxide production and lipid peroxidation in LPS-induced endotoxemia. Acta Med Okayama 2003;57(3):117-122.
25. Werner C.M., Hoch A., Gautier L., König M.A., Simmen H.P., Osterhoff G. Distraction test of the posterior superior iliac spine (PSIS) in the diagnosis of sacroiliac joint arthropathy. BMC Surg 2013;13:52.

26. Büyükafşar K., Yalçin I., Kurt A.H., Tiftik R.N., Sahan-Firat S., Aksu F. Rho-kinase inhibitor, Y-27632, has an antinociceptive effect in mice. Eur $J$ Pharmacol 2006;541(1-2):49-52.

27. Büyükafşar K., Levent A. Involvement of Rho/Rho-kinase signalling in the contractile activity and acetylcholine release in the mouse gastric fundus. Biochem Biophys Res Commun 2003;303(3):777-781.

28. Williams R.D., Novack G.D., van Haarlem T., Kopczynski C. Ocular hypotensive effect of the Rho kinase inhibitor AR12286 in patients with glaucoma and ocular hypertension. $A m \quad J$ Ophthalmol $2011 ; 152(5): 834-841$.

29. Büyükafşar K., Arikan O., Ark M., Seçilmiş A., Un I., Singirik E. Rho-kinase expression and its contribution to the control of perfusion pressure in the isolated rat mesenteric vascular bed. Eur J Pharmacol 2004;485(1-3):263-268.

30. Ramos S.C., Fonseca F.A., Kasmas S.H., Moreira F.T., Helfenstein T., Borges N.C., Moreno R.A., Rezende V.M., Silva F.C., Izar M.C. The role of soluble fiber intake in patients under highly effective lipidlowering therapy. Nutr J 2011;10:80.

31. Cevik C., Nugent K., Meyerrose G., Otahbachi M., Izgi C., Lyte M., Fish R.D. Rosuvastatin therapy does not affect serum MMP-13 or TIMP-1 levels in hypercholesterolemic patients. Tex Heart Inst J 2011;38(3):229-233. 